\title{
Fisk og flatorm i Vietnam
}

\author{
Vietnam er et fantastisk land i rask utvikling. Sykdomspanoramaet er endret fra tidligere infeksjonssykdom- \\ mer og ernæringproblemer til i tiltakende grad livsstilssykdommer og trafikkulykker. Men ikke alt endrer seg \\ med samme hast. I deler av landet er det lang tradisjon for å spise rå ferskvannsfisk. Dessverre risikerer man \\ da også å putte et helseproblem i munnen. Jeg fikk anledning til å jobbe med dette i en fordypningsperiode.
}

Tore Lier

tore.lier@unn.no

Avdeling for mikrobiologi og smittevern

Universitetssykehuset Nord-Norge

Tromsø

Det er vår i Nam Dinh-provinsen i NordVietnam. De nye risplantene er akkurat blitt plantet ut, og på alle kanter er markene dekket av et flott lysegrønt skjær. Foran meg har bonden gravd ut en firkantet dam på størrelse med en håndballbane. Vannet i dammen er grågrønt og med dårlig sikt. I dammen svømmer det trolig karpe eller tilapia. Rett ved siden av dammen er det bygd en grisebinge. Bingen er laget slik at avføringen fra grisene renner rett ut i dammen. Avføringen gjødsler dammen, gir god vekst av plankton som igjen er næring for fisken. Men avføringen kan også inneholde egg fra levertrematoder, en parasittisk flatorm. Her i nord vil det i så fall være egg fra Clonorchis sinensis. Eggene spises av en ferskvannssnegle, og inne i sneglen vil parasitten dele seg og danne larver som bryter ut av sneglen. Disse larvene vil oppsøke en fisk, bore seg inn under huden og kapsle seg inn i fiskekjøttet som små cyster, metacercariae, på kun en tidels millimeter. Mennesker og dyr smittes ved å spise fersk, ikke varmebehandlet fisk eller fiskeavfall. I duodenum kommer parasitten ut av cysten, kryper opp gallegangen og setter seg fast i de intrahepatiske gallegangene. Her vokser den raskt til en langstrakt og flat voksen orm på 1-2 centimeters lengde.

De fleste smittede har noen få ormer, mens enkelte har mange ormer. Sistnevnte er mer utsatt for å få feber, smerter, diaré og kroniske galleveissymptomer som kolelitiasis, kolecystitt og kolangitt (1). Men mest bekymringsfullt er økt risiko for kolangiokarsinom. Både levertrematoden $\mathrm{C}$ sinensis og den nært beslektede Opisthorchis viverrini er klassifisert som humane karsinogener (gruppe 1) av International Agency for Research on Cancer (2). Khon Kaenprovinsen i Thailand er høyendemisk for
$\mathrm{O}$ viverrini og har samtidig verdens høyeste forekomst av kolangiokarsinom, med en årlig insidensrate på 85 per 100000 personår, hvilket er 15 ganger høyere enn i det sørlige Thailand, der forekomsten av $\mathrm{O}$ viverrini er lav (3).

\section{Rå fisk}

Siden den eneste smittemåten for mennesker er å spise fersk, ikke ordentlig varmebehandlet fisk, bestemmes utbredelsen av $\mathrm{C}$ sinensis og $\mathrm{O}$ viverrini i høy grad av lokale matvaner (1). De aktuelle matrettene har, i likhet med gravet fisk i Skandinavia, lange kulturelle tradisjoner og betraktes ofte med en viss skepsis av utenforstående. Derfor blir få turister smittet, og levertrematoder er nokså sjeldne som importmedisinske kasus i Europa. Sushi er neppe en smitterisiko for levertrematoder fordi den som regel lages av saltvannsfisk. I tillegg bruker mange sushirestauranter av sikkerhetshensyn fisk som har vært frosset.

I Nam Dinh spiser man rå fisk skåret i tynne skiver dekket med rismel og sammen med urter og forskjellige sauser. Dette skjer som regel i hyggelig sosialt samvær hvor det også drikkes risbrennevin som kan fortrenge et ellers kjent budskap fra opplysende helsekampanjer. På vanlig vietnamesisk vis spises det med spisepinner direkte fra felles matfat. Det er hovedsakelig menn som spiser rå fisk. Slike sammenkomster har dype sosiale og kulturelle røtter og er selvfølgelig til glede for mange. I Thailand og Laos spises det retter med fermentert fisk, men denne prosessen er heller ikke tilstrekkelig til å drepe metacercariae. I en liten studie fra Nam Dinh fant man nokså overraskende at også de som oppga at de aldri hadde spist rå fisk, men som var i samme husholdning som fiskespisere, hadde høy forekomst av trematodeegg i avføring, $26 \%$, mot $39 \%$ hos dem som spiser rå fisk (4). Om dette skyldes at de allikevel har spist rå fisk eller kontaminasjon fra kjøkkenredskaper eller felles matfat, vet vi ennå ikke. Men hvis dette stemmer, må vi passe oss for ikke kun å rette tiltak mot gruppen som oppgir å ha spist rå fisk.

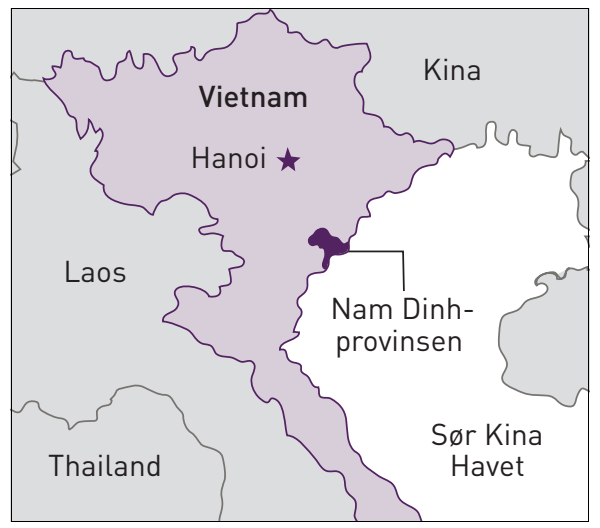

\section{Forekomst}

De aller fleste tilfellene av levertrematoder finner vi i Sørøst-Asia og Kina, men vi mangler gode data på hvor mange som er smittet. Dels skyldes dette at det er store variasjoner i prevalens innad i hvert land, avhengig av lokale mattradisjoner. Dessuten skaper små intestinale trematoder rot $i$ tallene. Dette er slektninger av levertrematodene, og de smitter på samme måte. Imidlertid forblir de intestinale trematodene i tarmlumen og gir langt mildere patologi, blant annet gir de ikke kolangiokarsinom.

Det er beskrevet nærmere 60 forskjellige arter hos menneske (5). Ved mikroskopi av avføring likner egg fra intestinale trematoder til forveksling på egg fra levertrematoder. For å skille mellom disse to hos mennesker må man enten bruke molkylærgenetiske metoder på eggene eller gi avførende midler etter behandling, samle voksne ormer i avføring og artsbestemme disse etter farging. Begge disse metodene er underholdende og interessante, men ressurskrevende. I de aller fleste studier og i klinisk praksis benyttes kun mikroskopi av avføring hvor man ikke kan skille mellom levertrematoder og intestinale trematoder.

Det er også vanlig å være bærer av flere ulike arter samtidig (6). Man anslår at ti millioner mennesker er smittet av $\mathrm{O}$ viverrini, de fleste i Thailand. Det er antatt at 35 millioner er smittet av $\mathrm{C}$ sinensis, hvorav 15 millioner er i Kina (1). Det er påfallende at man i Kina i 2005 viste til at det hadde vært 
en økning i antallet tilfeller C sinensis på hele $75 \%$ i det forgående tiår, mens antallet tilfeller med innvollsorm (spolorm, hakeorm og piskeorm) samt flatormen Schistosoma japonicum hadde hatt en nesten tilsvarende reduksjon $(7,8)$. Hovedårsakene til reduksjonen, både for innvollsormer og schistosomiasis, er for det første storstilte kontrollprogram, hovedsakelig basert på masseadministrasjon av medikamenter til store befolkningsgrupper. For det andre har sannsynligvis en bedring i sosioøkonomiske forhold hatt betydning $(7,8)$. Men hvorfor er det tilsynelatende en så kraftig økning av levertrematoder? En av forklaringene kan være en kraftig vekst i fiskeoppdrett (9).

\section{Akvakultur}

Mange av de viktigste viltfangede fiskeartene i verden er maksimalt utnyttet eller overbeskattet, med en stabil årlig fangst på 90 millioner tonn. Akvakultur har derimot hatt en kraftig vekst på vel $6 \%$ hvert år, og utgjorde 53 millioner tonn på verdensbasis i 2008 (10). Storparten av akvakulturproduksjonen forgår i Asia. Alle de seks landene som i 2008 hadde en produsjon i akvakultur på over én million tonn er asiatiske. Kina alene sto for $62 \%$ av den totale produksjonen i verden, mens Vietnam kom på en tredjeplass (10).

Figur 1 viser veksten i produksjon av ferskvannsoppdrettsfisk i Vietnam siden 1984 (11). Kina har hatt en tilsvarende utvikling og produserte 19 millioner tonn ferskvannsfisk i 2009, mot 0,8 millioner tonn i 1979 (11). Karpe er den viktigste artsgruppen og utgjør $39 \%$ av verdens totale akvakulturproduksjon (10). Karpe er en utmerket mellomvert for levertrematoder. Det meste av fisken som eksporteres fra Asia til vestlige land fryses. Fryst fisk fra Vietnam har til og med funnet veien til min lokale Prix-butikk i Tromsø. Nedfrysning dreper metacercariaene. Men fisk kjøpt lokalt på markeder i asiatiske land skal helst være fersk, gjerne levende, og utgjør dermed en smitterisiko.

Tallene ovenfor er offisielle tall hentet fra FNs mat- og jordbruksorganisasjon. De reelle tallene er trolig langt høyere, siden uttallige små dambruk rettet mot eget forbruk eller salg på det lokale marked ikke er tatt med (9). Akvakultur er blitt en viktig kilde til arbeidsplasser, kontanter og rimelig animalsk protein. Alle tre kan være mangelvare hos fattig befolkning på landsbygda i mange utviklingsland. Sannsynligvis vil viktigheten fortsette å øke i takt med jordas voksende befolkning og en bedring i levekår. Men så må vi også være oppmerksom på fiskerelaterte sykdommer.

\section{Behandling og forebygging}

Behandling av ukomplisert levertrematose er relativt enkelt. Praziquantel er et middel med god effekt og få alvorlige bivirkninger (1). Men siden de fleste har få symptomer

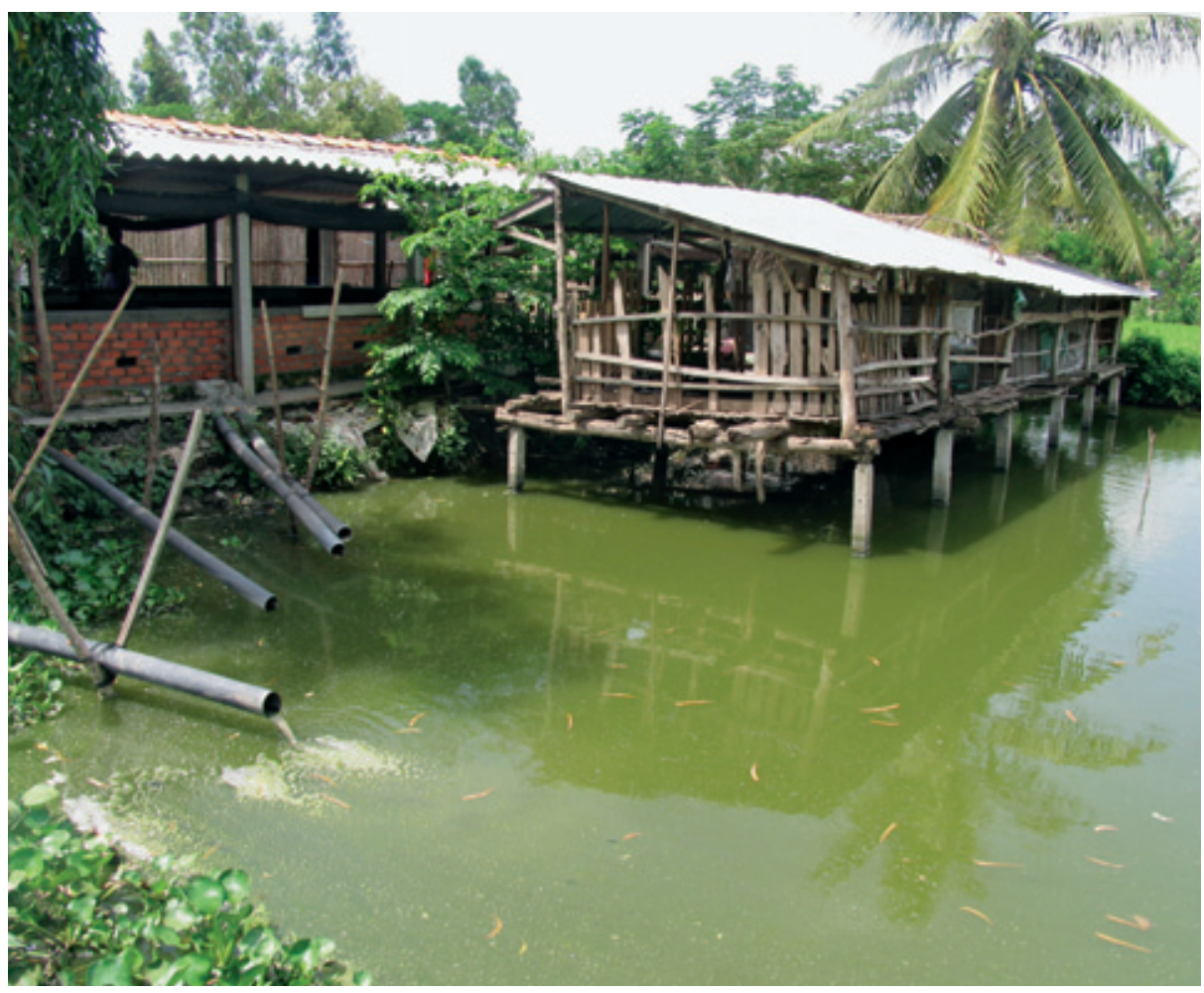

Dam for fiskeoppdrett med tilsluttende grisebinge. Foto FIBOZOPA. Gjengitt med tillatelse

og derfor ikke oppsøker behandling, blir forebygging og kontroll av sykdommen viktig. National Institute for Malariology, Parasitology and Entomology og Research Institute for Aquaculture er to institusjoner som beskjeftiger seg med dette i det nordlige Vietnam. De siste er støttet av danske Danida gjennom det såkalte FIBOZOPAprosjektet (12). Ingen vet hva som er den mest effektive metoden for å kontrollere infeksjonen. Parasittens livssyklus kan brytes i flere ledd. I Vietnam har det vært gjort studier med utsetting av svart karpe, en fisk med et imponerende sett jekselformede tenner som er i stand til å knuse snegler. I et annet prosjekt gjøres det omfattende ombygging rundt dammene for å hindre fekalt tilsig (i stedet tilsettes kunstig fôring), og samtidig fjernes sneglene i dammen. Foreløpige data tyder på at dette reduserer forekomsten av parasitter $i$ fisken betydelig (Jesper H. Clausen, per-
Produksjon av ferskvannsfisk (i 1000 tonn)

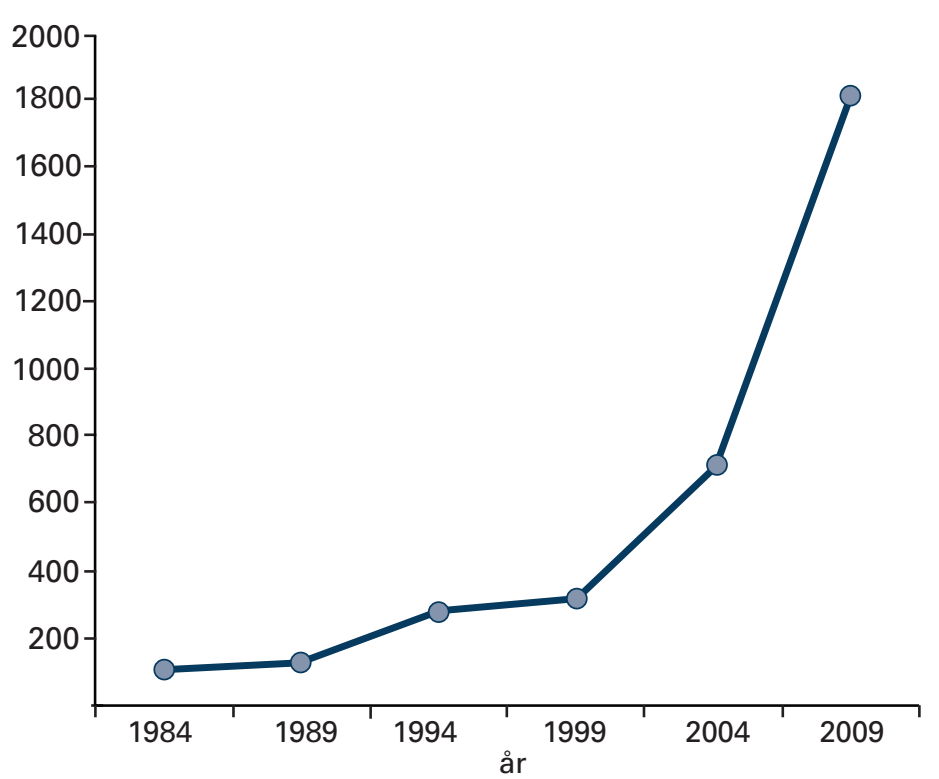

Figur 1 Produksjon av ferskvannsfisk i akvakultur i Vietnam 1984-2009 (i tusen tonn). Basert på tall fra Food and Agriculture Organization of the United Nations (11) 


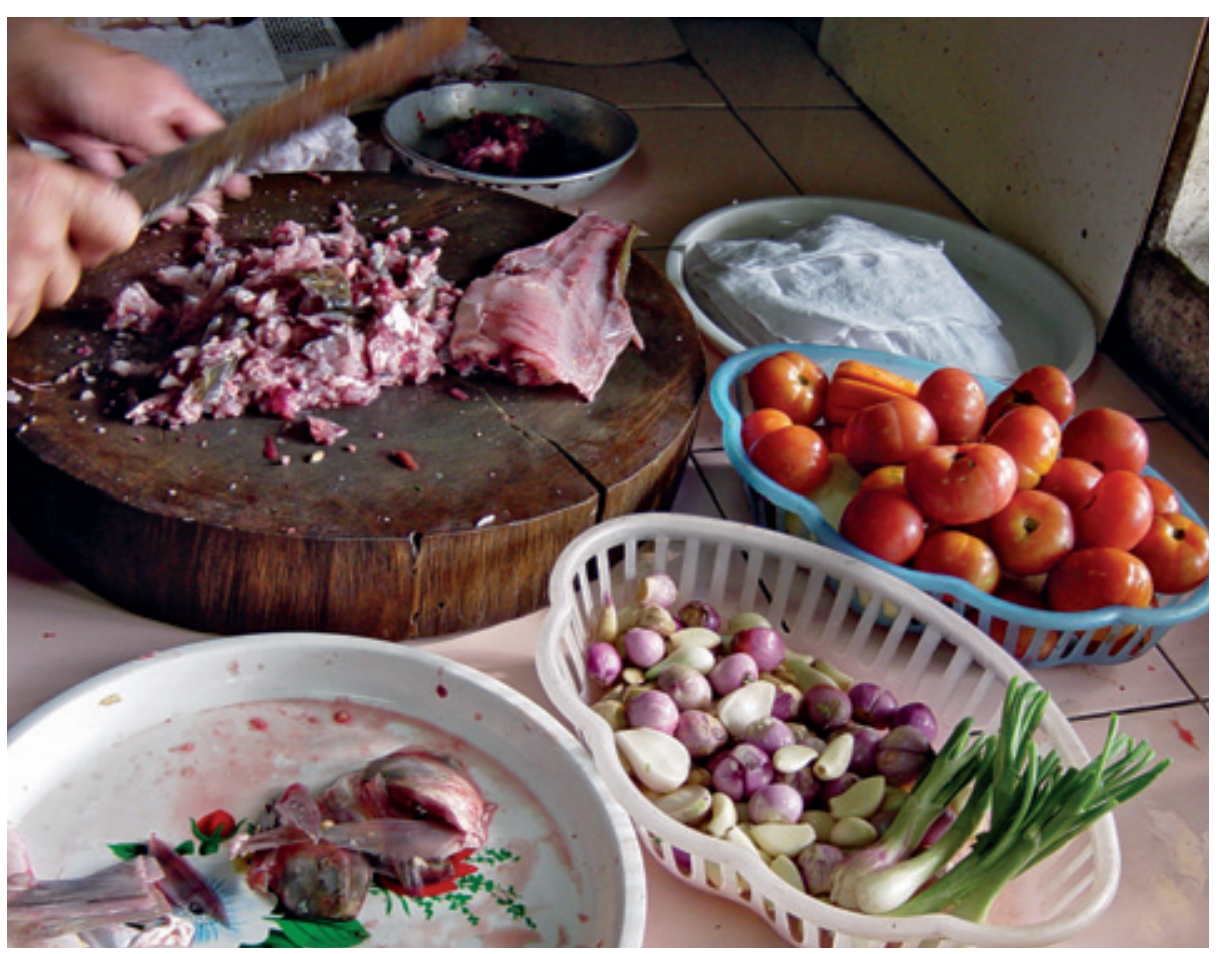

Tilberedning av rett med rå fisk. Foto FIBOZOPA. Gjengitt med tillatelse

sonlig meddelelse). Det utrydder imidlertid ikke parasitten fra dammene, for antakelig skal det ikke så mange egg og snegler til for å holde det gående.

En annen mulighet er å hindre at mennesker blir smittet, eller i hvert fall hindre at de utvikler alvorlig sykdom. Opplysningsarbeid om farene ved å spise rå fisk hører naturlig med her. Hovedstrategien til WHO for å bekjempe flere av de mest utbredte ormesykdommene i verden baserer seg hovedsakelig på medikamentell massebehandling, som oftest årlig, av store befolkningsgrupper. Mange titalls millioner behandlingsdoser brukes hvert år i kontrollprogram for innvollsormer, schistosomiasis, filariasis og andre parasittære ormer (13). I mange tilfeller gir dette en kraftig reduksjon i prevalens og morbiditet. Denne strategien har hittil kun i begrenset omfang vært fors $ø$ kt for levertrematoder, og effekten har knapt vært evaluert.

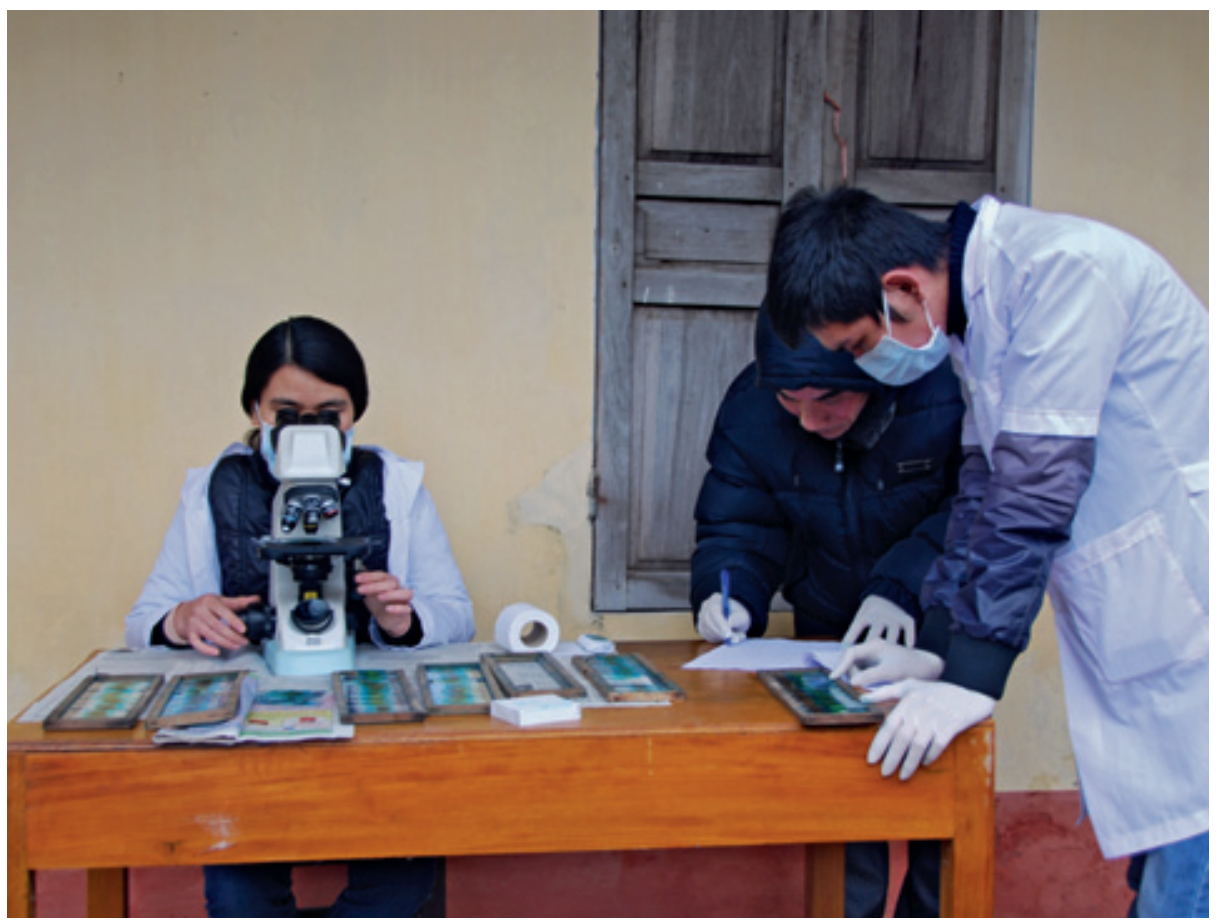

\section{Se fremover}

På en lav plastikkrakk lent mot husveggen sitter en eldre herre med langt, grått flippskjegg og minner meg om de ikoniske bildene av Ho Chi Minh, som man ser overalt i Vietnam. Han nikker og hilser: «Xin chao». Hver gang jeg møter eldre mennesker, kan jeg ikke la være å tenke på hva de må ha opplevd i dette landet som har sett så mye av okkupasjon og strid med Kina, Frankrike, Japan og USA. Men det dveles sjelden ved fortiden. Jeg nikker og hilser tilbake. Som parasittinteressert lege undrer jeg også på hvor mye en mann som han vet om risikoen ved å spise rå fisk. Hvis han vet, vil han i så fall være villig til å gi avkall på det? Finne et annet samlingspunkt for det sosiale samværet? Slutte å spise rå fisk i naboens bryllup? Det er jeg ikke så sikker på, men en forutsetning for å velge er jo først å vite.

\section{Tore Lier (f. 1966)}

er ph.d., spesialist i medisinsk mikrobiologi og overlege ved Avdeling for mikrobiologi og smittevern, Universitetssykehuset Nord-Norge. Hans doktorgrad omhandlet Schistosoma japonicum-infeksjoner.

Ingen oppgitte interessekonflikter.

\section{Litteratur}

1. Keiser J, Utzinger J. Food-borne trematodiases Clin Microbiol Rev 2009; 22: 466-83.

2. World Health Organization. International Agency for Research on Cancer. List of classifications. http://monographs.iarc.fr/ENG/Classification/ index.php (20.2.2011)

3. Sripa B, Kaewkes S, Sithithaworn P. Liver fluke induces cholangiocarcinoma. PLoS Med 2007; 4: e201

4. Phan VT, Ersbøll AK, Do DT et al. Raw-fish-eating behavior and fishborne zoonotic trematode infection in people of northern Vietnam. Foodborne Pathog Dis 2011; 8: 255-60.

5. Chai JY, Shin EH, Lee SH et al. Foodborne intestinal flukes in Southeast Asia. Korean J Parasitol 2009; 47 (suppl): S69-102.

6. Dung DT, De NV, Waikagul J et al. Fishborne zoonotic intestinal trematodes, Vietnam. Emerg Infect Dis 2007; 13: 1828-33.

7. Review on the epidemiological profile of helminthiases and their control in the western Pacific region, 1997-2008. Manila: World Health Organization, 2008.

8. Zhou XN, Bergquist R, Leonardo L et al. Schistosomiasis japonica control and research needs. Adv Parasitol 2010; 72: 145-78.

9. Keiser J, Utzinger J. Emerging foodborne trematodiasis. Emerg Infect Dis 2005; 11: 1507-14.

10. FAO yearbook 2008. Roma: Food and Agriculture Organization of the United Nations, 2010.

11. Global Aquaculture Production 1950-2008. Food and Agriculture Organization of the United Nations. www.fao.org/fishery/statistics/globalaquaculture-production/query/en (15.4.2011).

12. FIBOZOPA. Fishborne Zoonotic Parasites in Vietnam. http://fibozopa.ria1.org (7.3.2011).

13. Hotez PJ, Fenwick A, Savioli L et al. Rescuing the bottom billion through control of neglected tropical diseases. Lancet 2009; 373: $1570-75$. 